\title{
Simultaneous heavy metal removal and anthracene biodegradation by the oleaginous bacteria Rhodococcus opacus
}

\author{
Lalit Goswami $^{1}$ N. Arul Manikandan ${ }^{2}$ Kannan Pakshirajan ${ }^{1,3}$ - G. Pugazhenthi ${ }^{1,2}$
}

Received: 16 September 2016/ Accepted: 23 December 2016/Published online: 24 April 2017

(c) The Author(s) 2017. This article is an open access publication

\begin{abstract}
This study investigated simultaneous heavy metals removal and anthracene biodegradation by Rhodococcus opacus at different initial anthracene concentrations in the range 50-200 $\mathrm{mg} \mathrm{L}^{-1}$. The heavy metals tested were $\mathrm{Fe}(\mathrm{III}), \mathrm{Cu}(\mathrm{II}), \mathrm{Zn}$ (II), $\mathrm{Cd}(\mathrm{II}), \mathrm{Ni}(\mathrm{II})$, and $\mathrm{Pb}$ (II) at $10 \mathrm{mg} \mathrm{L}^{-1}$ initial concentration: The organism was found to be well capable of removing the heavy metals along with high anthracene biodegradation efficiency. However, anthracene biodegradation rate by the organism was reduced due to these heavy metals. In addition, the heavy metals effect on $R$. opacus biomass growth followed the order: $\mathrm{Cd}>\mathrm{Ni}>\mathrm{Pb}>\mathrm{Cu}>\mathrm{Zn}>\mathrm{Fe}$. The total time to anthracene biodegradation increased from 144 to $216 \mathrm{~h}$ in the presence of $\mathrm{Fe}, \mathrm{Zn}, \mathrm{Cu}$, or $\mathrm{Pb}$, and it was up to $240 \mathrm{~h}$ in the presence of $\mathrm{Cd}$ or Ni. Compared with $70.2 \%(\mathrm{w} / \mathrm{w})$ lipid accumulation by the bacterium in the absence of these heavy metals, a significant decline in the same was observed in the presence of the different heavy metals. These values were 41.2, 44.1, 52.1, 54.1, 58.6, and 63.1\% (w/w) for $\mathrm{Cd}, \mathrm{Ni}, \mathrm{Pb}, \mathrm{Cu}, \mathrm{Zn}$, and $\mathrm{Fe}$, respectively. Field emission scanning electron microscopy integrated with energy dispersive $\mathrm{X}$-ray spectroscopy and transmission electron microscopy of the biomass grown in the presence and absence of these heavy metals further confirmed a
\end{abstract}

Kannan Pakshirajan

pakshi@iitg.ernet.in

1 Center for the Environment, Indian Institute Technology Guwahati, Guwahati, Assam 781039, India

2 Department of Chemical Engineering, Indian Institute Technology Guwahati, Guwahati, Assam 781039, India

3 Department of Biosciences and Bioengineering, Indian Institute Technology Guwahati, Guwahati, Assam 781039, India change in morphology of the bacterium due to the heavy metals. Fourier transmission infrared spectroscopy spectra of the biomass obtained during its growth in the presence and absence of the heavy metals confirmed the involvement of $\mathrm{N}-\mathrm{H}, \mathrm{C}-\mathrm{H}$ bend, $-\mathrm{CH}_{2}-(\mathrm{C}=\mathrm{O}), \mathrm{C}-\mathrm{N}$ stretch, $\mathrm{C}-\mathrm{H}$ and $\mathrm{O}-\mathrm{H}$ bending, and $-\mathrm{C}-\mathrm{Cl}$ groups on the biomass for heavy metal uptake by the bacterium.

Keywords Biodegradation - Anthracene - Heavy metals · Rhodococcus opacus · Lipid accumulation

\section{Introduction}

Release of different pollutants into the environment has increased noticeably, thereby diminishing the environment quality to frightening levels (Kiran et al. 2016; Roy et al. 2015). These pollutants are known to affect both the living and non-living assets of the biosphere via numerous routes (Ye et al. 2013). Among the different environmental pollutants, polycyclic aromatic hydrocarbons (PAHs) and heavy metals (HMs) are the most important because of their persistence, recalcitrance, abundance, and toxicity in the environment (Arul Manikandan et al. 2016; Titaley et al. 2016; Gopi Kiran et al. 2015; Samanta et al. 2002).

Heavy metals, such as copper, zinc, and iron, despite being toxic at a high concentration, they are essential for the growth of microorganisms in trace amounts (Baldrian et al. 2000; Hiroki et al. 1985). PAHs are toxic, mutagenic, carcinogenic, teratogenic, and persistent in the environment mainly due to their hydrophobic and water insoluble properties. Some PAHs are known to be a human skin photosensitizer, mild allergen, whereas some other PAHs are reported to cause haemolytic anaemia and nephrotoxicity (Bücker et al. 1979). Heavy metals are widely used in 
metal finishing, leather tanning, electroplating, nuclear power plant, and textile industries, whereas PAHs are ubiquitously found at wood preservation plants, industrial sites associated with petroleum and coal tar manufacturing, gas plants, runoff from asphalt pavement, and combustion processes (Kiran et al. 2016; Hadibarata and Kristanti 2012; Yap et al. 2011; Mahanty et al. 2008; Samanta et al. 2002). Therefore, industrial effluent containing these contaminants when released from the main stream affects each other's biodeterioration and biotransformation by microorganism. For instance, heavy metals, including cadmium $(\mathrm{Cd})$, lead $(\mathrm{Pb})$, and nickel $(\mathrm{Ni})$, are shown to adversely affect biodegradation of organic contaminants in the environment (Atagana 2006; Riis et al. 2002; Sokhn et al. 2001).

Remedial technologies, viz., volatilization, chemical oxidation, adsorption, photo-oxidation, and bioaccumulation, have been investigated for treating PAHs contaminated systems (Haritash and Kaushik 2009). Microbial biodegradation and biotransformation is proving to be more successful than these conventional techniques considering such issues as safety, cost, degradation efficiency, etc. Bacterial species, including Bacillus, Burkholderia, Mycobacterium, Pseudomonas, Rhodococcus, and Sphingomonas, are known to degrade/mineralize different PAHs into simpler non-hazardous metabolites. Organisms belonging to the actinomycete group are well known for PAHs utilization along with triacylglyceride (TAG) accumulating capability, which can be further transesterified for potential biodiesel application. Rhodococcus, Nocardia, Mycobacterium, and Streptomyces sp. are few of them (Kumar et al. 2015; Kurosawa et al. 2010; Mehta and Chavan 2009).

In general, PAHs biodegradation using bacteria, algae, and fungi have widely been reported in the literature (Sasek et al. 2003; Daane et al. 2002; Alexander 1999; Cerniglia and Heitkamp 1989). But till date, there are no studies which were found in the literature on simultaneous uptake of heavy metals and PAH biodegradation. This is very important from the standpoint of designing biological processes for treating a variety of pollutants in mixture. Therefore, this study evaluated the simultaneous heavy metal removal and anthracene biodegradation by $R$. opacus with a view to assess the feasibility of remediating aqueous environment contaminated with both PAH and heavy metals. Anthracene, a tri-ring $\mathrm{PAH}$, is often utilized in dye and insecticide manufacturing and material coating industries. Uptake of anthracene via numerous routes in the body imposes toxicity to the skin, blood, intestine, and the lymphatic system, thus leading to tumors, edema, itching, and upsurge of fluids in tissues (Wieczorek et al. 2015). The heavy metals tested for this removal by $R$. opacus were $\mathrm{Fe}(\mathrm{III}), \mathrm{Cu}(\mathrm{II}), \mathrm{Zn}(\mathrm{II}), \mathrm{Cd}(\mathrm{II}), \mathrm{Ni}(\mathrm{II})$, and $\mathrm{Pb}(\mathrm{II})$.
Furthermore, the bacterial morphology and accumulated lipid globules during the bio-removal process were examined employing field emission scanning electron microscopy (FESEM) equipped with energy dispersive spectroscopy (EDX) and transmission electronic microscopy (TEM). Fourier transform infrared spectroscopy (FTIR) analysis was deployed to identify heavy metalbinding functional groups on the biomass for their removal.

\section{Materials and methods}

\section{Microorganism and culture conditions}

The bacterial strain (Rhodococcus opacus DSM 43205) utilized in this study was obtained from Microbial Type Cell Culture (MTCC, Chandigarh, India). The culture was primarily maintained by sub-culturing on Luria-Bertani (LB) agar plates at $4{ }^{\circ} \mathrm{C}$ and further preserved in $20 \%(\mathrm{v} / \mathrm{v})$ glycerol at $-80{ }^{\circ} \mathrm{C}$. For anthracene biodegradation, Bushnell-Hass minimal salt medium (BHMSM) (pH 7) was utilized (Lee and Cho 2009). The bacterial growth conditions were $30{ }^{\circ} \mathrm{C}$ temperature and $120 \mathrm{rpm}$ agitation speed.

\section{Chemicals and reagents}

Anthracene (99\% pure) was obtained from Himedia (Mumbai, India) with purity greater than 99\%. Analytical grade chemicals for preparing the bacterial growth media were procured from either Merck (Mumbai, India) or Himedia (Mumbai, India). All the chemicals except solvent used in this study for preparing the bacterial growth media and for its cultivation were of analytical grade and obtained from Himedia (Mumbai, India). HPLC grade dichloromethane (DCM) and acetonitrile were purchased from Spectrochem (Mumbai, India). Individual metal stock solutions of $\mathrm{Fe}(\mathrm{III}), \mathrm{Cu}(\mathrm{II}), \mathrm{Zn}$ (II), $\mathrm{Cd}(\mathrm{II}), \mathrm{Ni}(\mathrm{II})$, and $\mathrm{Pb}(\mathrm{II})$ of concentration $1000 \mathrm{mg} \mathrm{L}^{-1}$ each were prepared using $\mathrm{FeCl}_{3}, \mathrm{CuCl}_{2} \cdot 2 \mathrm{H}_{2} \mathrm{O}, \mathrm{ZnCl}_{2}, \mathrm{Cd}\left(\mathrm{NO}_{3}\right)_{2}, \mathrm{NiCl}_{2} \cdot 6 \mathrm{H}_{2} \mathrm{O}$, and $\mathrm{PbNO}_{3}$, respectively.

\section{Experiment setup}

Seed culture of the bacterial strain Rhodococcus opacus was prepared using BHMSM containing $20 \mathrm{mg} \mathrm{L}^{-1}$ of anthracene for studying the PAH biodegradation. For inoculum preparation, $1 \mathrm{~mL}$ of the culture obtained at its mid logarithmic growth phase was centrifuged $(8000 \mathrm{~g}$, $10 \mathrm{~min}$ ) to get pellets of intact bacterial cells. Following resuspension of the intact cells in BHMSM, 5\% (v/v) of these bacterial cells were inoculated into $250 \mathrm{~mL}$ Erlenmeyer flask containing $93 \mathrm{ml}$ of BHMSM and different initial anthracene concentrations in the range 
50-200 mg L ${ }^{-1}$ as the sole carbon and energy source. The final volume was made up to $100 \mathrm{~mL}$ by adding individual heavy metal stock solution to achieve an initial concentration of $10 \mathrm{mg} \mathrm{L}^{-1}$. The initial concentration used in this study was chosen based on a literature study by Kiran et al. (2016) and Pavasant et al. (2006) for heavy metals removal using microalgae and anaerobic sludge, respectively. Ten percentage of DCM was then added to dissolve the PAH. Flasks with no inoculum, but with the heavy metals, anthracene, and BHMSM were used as control in these experiments. The flasks were placed in an orbital incubator shaker set at $120 \mathrm{rpm}$ and $30{ }^{\circ} \mathrm{C}$. Sample aliquots were taken at regular time intervals for quantitative analysis of $R$. opacus biomass, lipids, residual anthracene, and heavy metals.

\section{Analytical methods}

\section{Analysis of anthracene and heavy metals}

Anthracene concentration in the samples was determined by high-pressure liquid chromatography (HPLC), (Varian Prostar 210, The Netherlands). A standard solution of anthracene was prepared using pure dichloromethane (HPLC grade). C-18 column Thermo hypersil ${ }^{\mathrm{TM}}$ was utilized $(100 \times 4.6 \mathrm{~mm})$ with an injection volume of $20 \mu \mathrm{L}$. Two mobile phases were used in the analysis: Milli Q water and acetonitrile in the ratio 70:30 with a constant flow rate of $1 \mathrm{~mL} \mathrm{~min}^{-1}$. The eluted compounds were detected at $254 \mathrm{~nm}$ and the retention time was compared with that of a known standard. The following Eq. (1) was used to determine the \% anthracene degradation:

Anthracene biodegradation (\%)

$$
=\left[\frac{\left(C_{0}-C_{\mathrm{f}}\right)-C_{\mathrm{n}}}{C_{0}}\right] \times 100
$$

where $C_{o}$ is the initial anthracene concentration; $C_{\mathrm{f}}$ and $C_{\mathrm{n}}$ are the final concentrations in the test and control flasks, respectively.

Heavy metal concentration in the samples was analyzed by atomic absorption spectroscopy (Varian, AA240, The Netherlands) as per the American Public Health Association standards (APHA 2005).

\section{Rhodococcus opacus biomass growth}

Rhodococcus opacus cell density was determined by measuring its absorbance at $660 \mathrm{~nm}$ using a UV-Vis spectrophotometer (Agilent Technologies, Cary 100 series, Singapore). The bacterial growth was determined based on a standard graph plotted between $\mathrm{OD}_{660}$ versus cell dry weight $(\mathrm{CDW})$. The specific anthracene uptake rate and specific lipid accumulation rate by $R$. opacus were estimated as per the following Eqs. 2 and 3, respectively:

Specific anthracene uptake rate $\left(q_{\mathrm{A}}\right)=\left(\frac{1}{C_{p}} \frac{d C_{p}}{d t}\right)$

Specific lipid accumulation rate $\left(q_{\mathrm{L}}\right)=\left(\frac{1}{C_{L}} \frac{d C_{L}}{d t}\right)$.

In the above equation, $q_{\mathrm{A}}$ is the specific anthracene uptake rate $\left(\mathrm{h}^{-1}\right), q_{\mathrm{L}}$ is the specific lipid accumulation rate $\left(\mathrm{h}^{-1}\right)$, and $C_{\mathrm{p}}$ and $C_{\mathrm{L}}$ are the concentrations $\left(\mathrm{mg} \mathrm{L}^{-1}\right)$ of anthracene and lipid corresponding to time $t(\mathrm{~h})$, respectively.

\section{Total lipid content}

Total lipid content in the biomass was determined by the standard chloroform and methanol extraction procedure with minor modifications (Kumar et al. 2015; Folch et al. 1957). $5 \mathrm{~mL}$ of sample aliquot was centrifuged $(8000 \mathrm{~g}$, $10 \mathrm{~min}$ ) and the resultant pellet was mixed with $2 \mathrm{~mL}$ solvent mixture containing chloroform and methanol (2:1 $\mathrm{v} / \mathrm{v}$ ), and kept over for $12 \mathrm{~h}$. The mixture was then centrifuged $(8000 \mathrm{~g}, 15 \mathrm{~min})$ and the lower phase containing lipid dissolved in chloroform was transferred into a preweighed centrifuge tube $\left(\mathrm{W}_{1}\right)$. The extraction procedure was repeated twice. The centrifuge tube containing the total volume of the supernatant collected from each extraction was subjected to $60{ }^{\circ} \mathrm{C}$ in an oven to evaporate the solvents and then reweighed $\left(\mathrm{W}_{2}\right)$. The amount of lipid in the samples was calculated from the difference between $\mathrm{W}_{1}$ and $\mathrm{W}_{2}$.

\section{Characterization of the bacterial biomass}

\section{FESEM and TEM analyses}

Changes in the bacterial surface morphology observed due to simultaneous uptake of heavy metals and anthracene were examined by field emission scanning electron microscopy (FESEM) (Zeiss, Sigma, Germany). The bacterium grown in the presence of both anthracene and $\mathrm{Cu}$ as the heavy metal was used for this analysis. $1 \mathrm{~mL}$ of the bacterial culture was centrifuged $(10,000 \mathrm{~g}, 10 \mathrm{~min})$ and washed twice with sterile milliQ water. The pellet obtained was diluted ten times with milliQ water and vortexed. Unit drop of this sample was mounted on aluminum stubs over double-sided carbon tape and dried overnight at $30{ }^{\circ} \mathrm{C}$ prior to the analysis. After drying, the sample was coated with thin gold layer by sputter coater before FESEM observation. The spectra obtained were compared with the biomass grown in the absence of anthracene and heavy metals. 
Fig. 1 Time profile of

a anthracene biodegradation;

b biomass grown and $\mathbf{c}$ total

lipid accumulation by $R$. opacus

in the presence of different

heavy metals (initial anthracene

concentration $=100 \mathrm{mg} \mathrm{L}^{-1}$;

initial heavy metal

concentration $=10 \mathrm{mg} \mathrm{L}^{-1}$ ) (a)

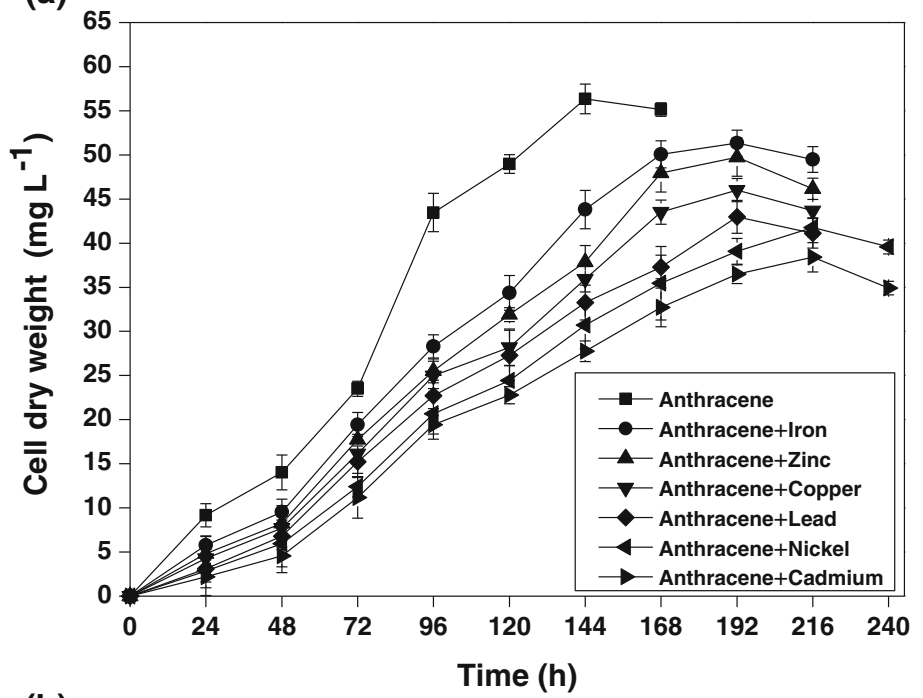

(b)

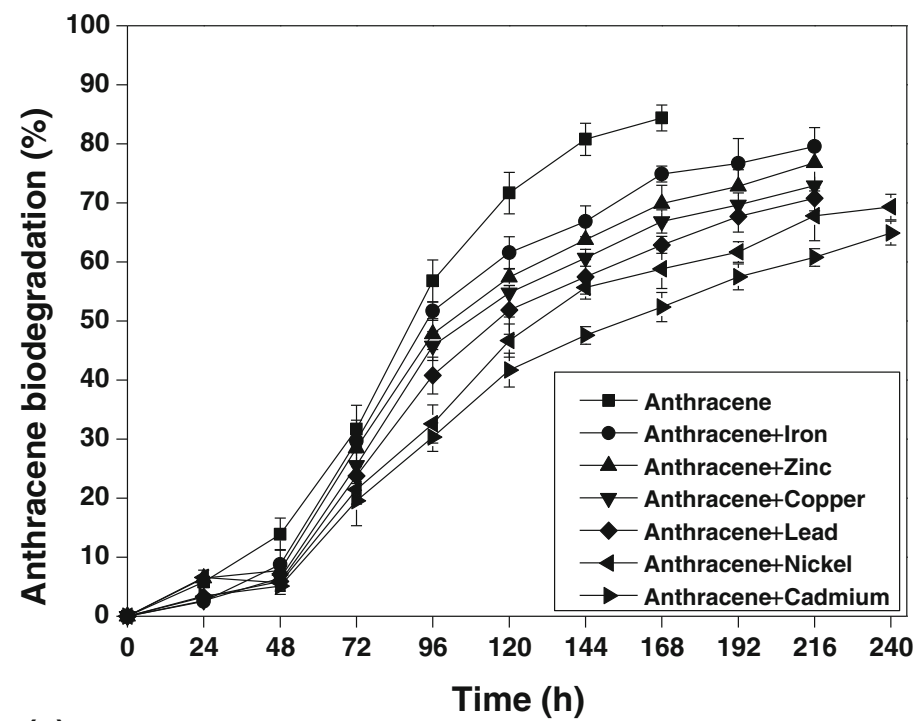

(c)

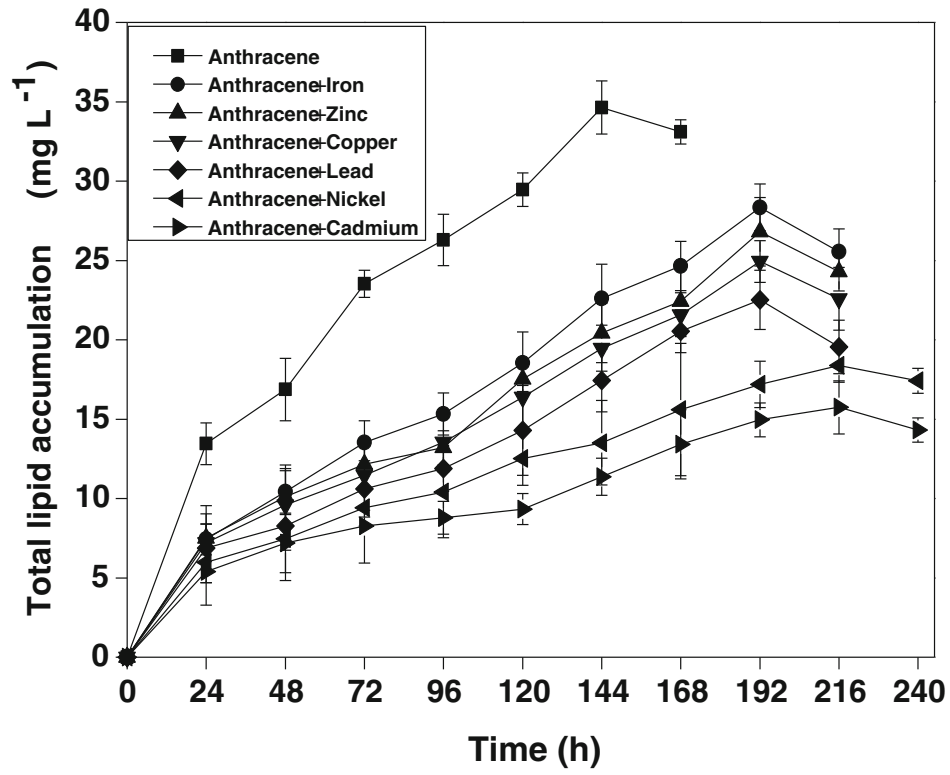


For determining the size of the accumulated lipid by $R$. opacus, transmission electron microscopy (TEM) (JEOL, JEM2100, Japan) at $200 \mathrm{kV}$ was carried out. Single drop of the sample, prepared as mentioned above under FESEM analysis, was casted on copper grid coated with carbon (Tedpell, USA) and dried overnight at $30{ }^{\circ} \mathrm{C}$ before the analysis.

\section{FTIR and FESEM-EDX analysis}

Infrared spectroscopy of the biomass grown in the presence and absence of the pollutants was carried out by Fourier transform infrared spectrometer with attenuated total reflectance (ATR) attachment under dry air at room temperature (PerkinElmer, Spectrum Two, Singapore). Sample aliquots were centrifuged $(8000 \mathrm{~g}, 10 \mathrm{~min})$ followed by

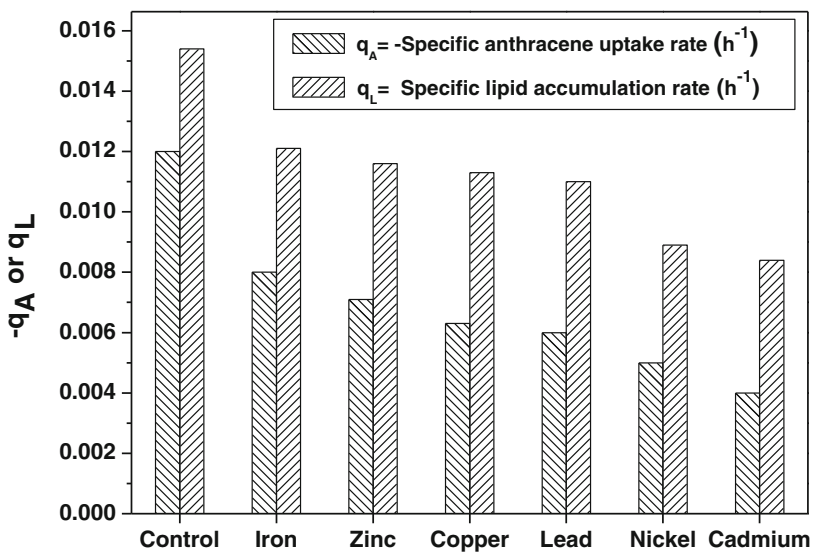

Fig. 2 Estimated specific anthracene uptake rate and specific lipid accumulation rate by $R$. opacus (initial anthracene concentration $=100 \mathrm{mg} \mathrm{L}^{-1}$, initial heavy metal concentration $=10 \mathrm{mg} \mathrm{L}^{-1}$ ) washing with distilled water and the pellets obtained were vacuum dried prior to FTIR analysis. The samples were uniformly mixed with $\mathrm{KBr}$ in 100:1 ratio. The analysis was performed over the entire wave number range with 20 consecutive scans at a $4.0 \mathrm{~cm}^{-1}$ resolution. FTIR spectra were taken under the transmittance mode.

For FESEM-EDX analysis, biomass samples were vacuum dried and mounted on aluminum stubs over double-sided carbon tape followed by double coating with thin gold layer by sputter coater.

\section{Results and discussion}

\section{R. opacus biomass growth and anthracene biodegradation in the presence of heavy metals}

The capability of $R$. opacus to simultaneously biodegrade anthracene and accumulate lipids in the presence of different heavy metals was studied and is shown in Fig. 1a-c. These results reveal that in the presence of heavy metals, the bacterium showed a reduced anthracene biodegradation rate and efficiency along with a decrease in both biomass and total lipid accumulation. A separate set of flasks without the inoculum served as the control in the experiment, which indicated that the abiotic loss of the PAH was within the range 1.6-4.7\%. Figure 1a reveals a clear difference in the lag phase of biomass growth in the presence and absence of the heavy metals. The anthracene biodegradation efficiency decreased sharply in the presence of the heavy metals when compared to that of the control (Fig. 1b). The total time for maximum biomass growth also increased from 168 to $216 \mathrm{~h}$ in the presence of $\mathrm{Fe}, \mathrm{Cu}, \mathrm{Zn}$, and $\mathrm{Pb}$ and to
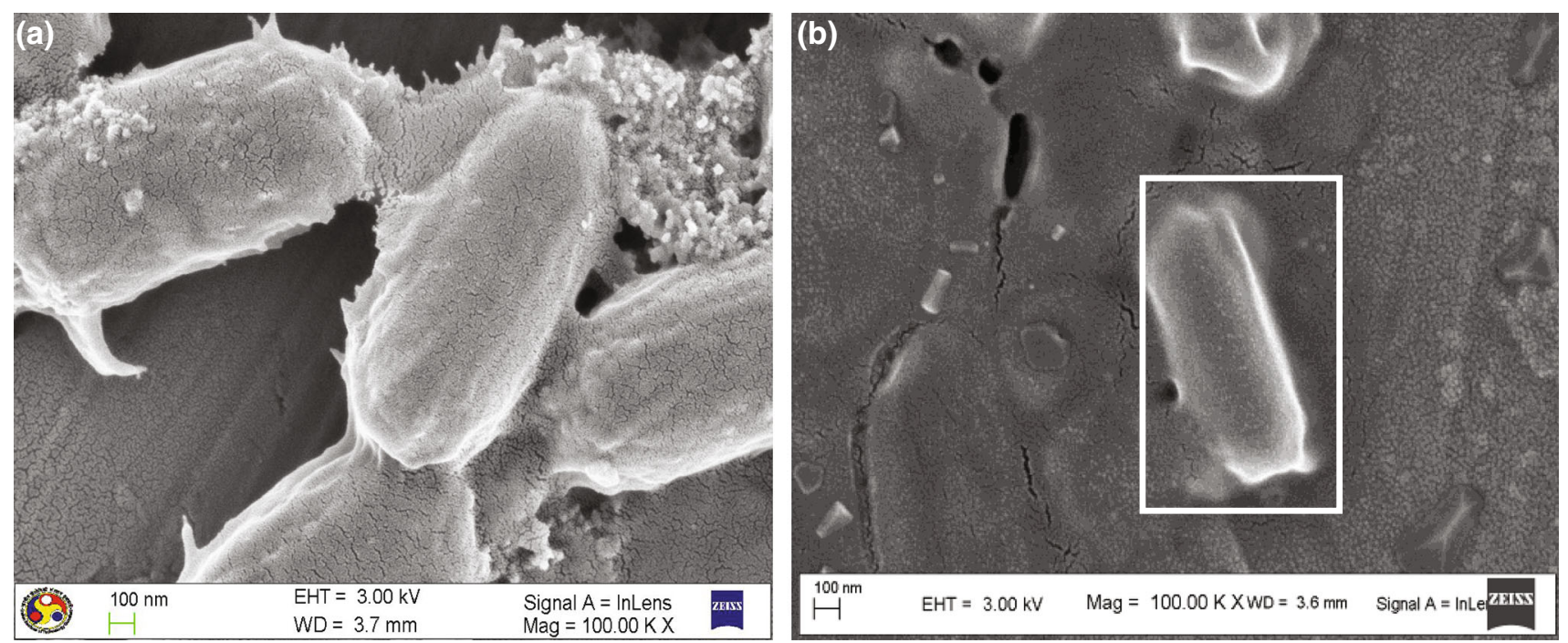

Fig. 3 FESEM image of the bacteria a control biomass and $\mathbf{b}$ heavy metal loaded biomass 
$240 \mathrm{~h}$ in the presence of $\mathrm{Cd}$ and $\mathrm{Ni}$. The heavy metals effect on $R$. opacus biomass growth, lipid accumulation, and anthracene biodegradation followed the order: $\mathrm{Cd}>\mathrm{Ni}>\mathrm{Pb}>\mathrm{Cu}>\mathrm{Zn}>\mathrm{Fe}$. A sharp decline in anthracene biodegradation efficiency in the presence of the heavy metals is observed after 72-84 h, which correlates well with the decline in the cell dry weight of the bacterium. Figure 2 further shows that a decrease in both specific anthracene consumption rate $\left(-q_{\mathrm{A}}\right)$ and lipid accumulation rate $\left(q_{\mathrm{L}}\right)$ is observed in the presence of these heavy metals.

A similar trend in biomass growth and total lipid content in the presence of the heavy metals is observed for the other initial anthracene concentration $\left(100 \mathrm{mg} \mathrm{L}^{-1}\right)$ (data not shown). These results suggested that the heavy metals are primarily responsible for inhibition of key enzymes involved in anthracene uptake, biomass growth, and lipid accumulation by R. opacus (Maria et al. 2013). The effect due to heavy metals on biomass growth, anthracene biodegradation, and lipid accumulation by $R$. opacus correlates well with the observation that the residual concentration of heavy metals at $24 \mathrm{~h}$ of the experiments is found to be nil (data not shown). The heavy metal removal mechanism by the organism is primarily attributed to their quick biosorption followed by their uptake inside the cells, which is consistent with (a)

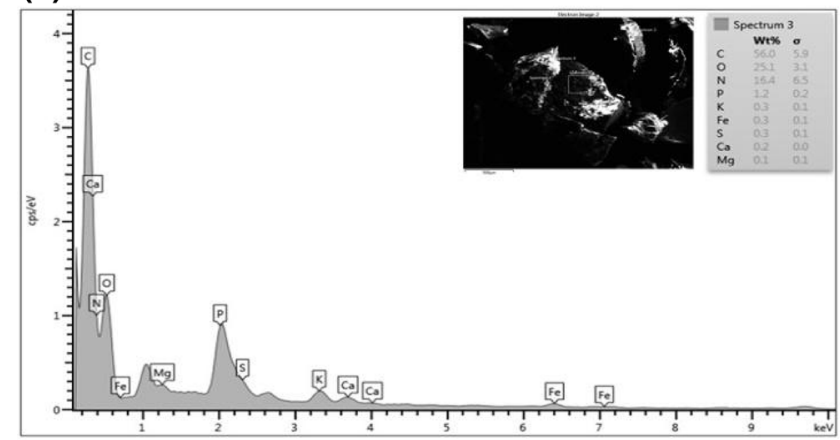

(c)

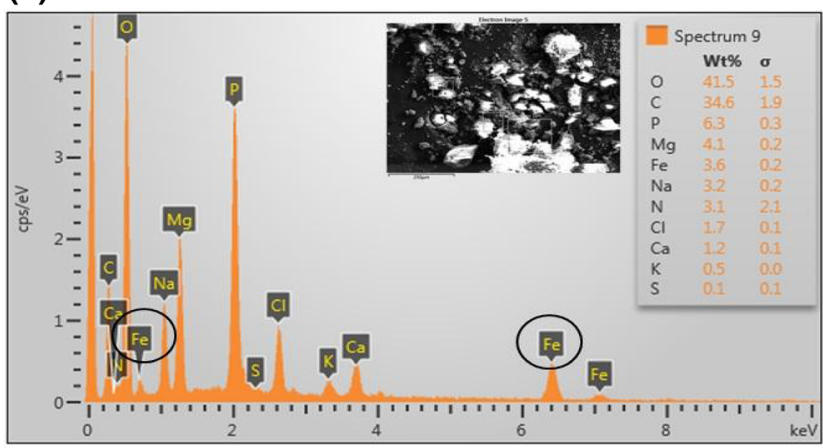

(e)

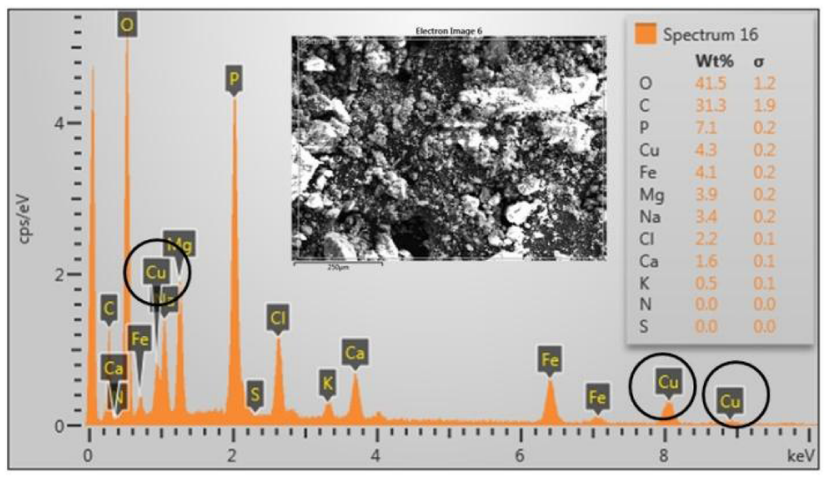

(b)

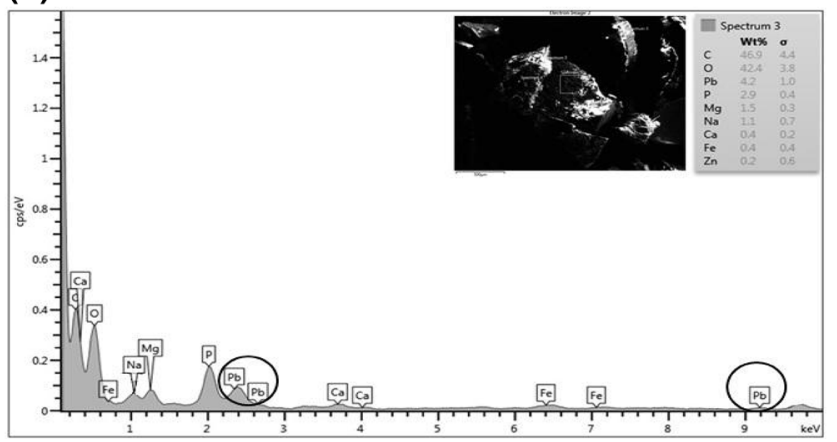

(d)

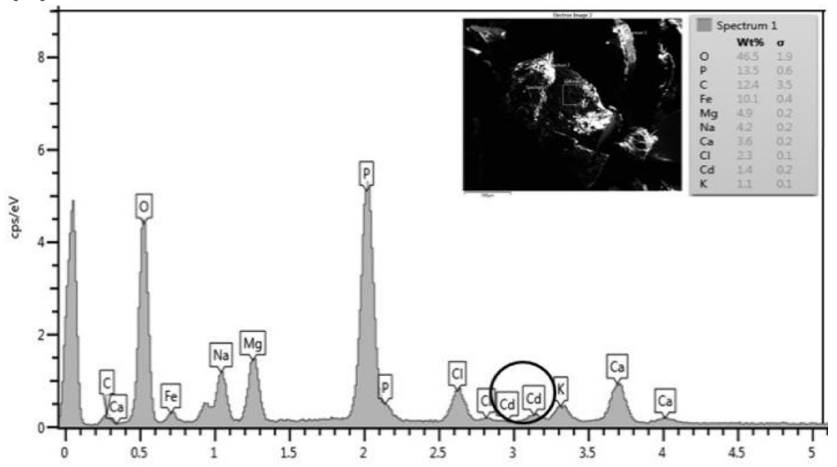

(f)

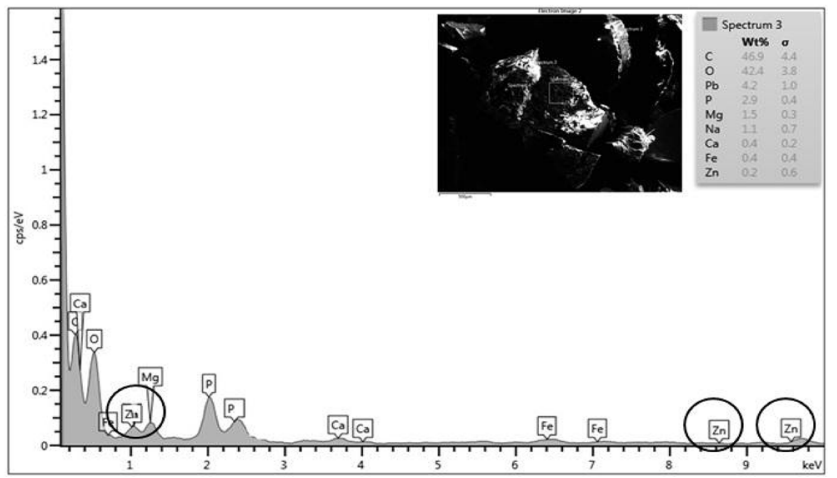

Fig. 4 EDX spectrum of a control biomass and b biomass loaded with $\mathrm{Pb}$ (II); $\mathbf{c} \mathrm{Fe}(\mathrm{III})$; $\mathbf{d} \mathrm{Cd}(\mathrm{II})$; e $\mathrm{Cu}$ (II); f $\mathrm{Zn}$ (II). Insert shows the FESEM image of the biomass loaded with the respective metals 

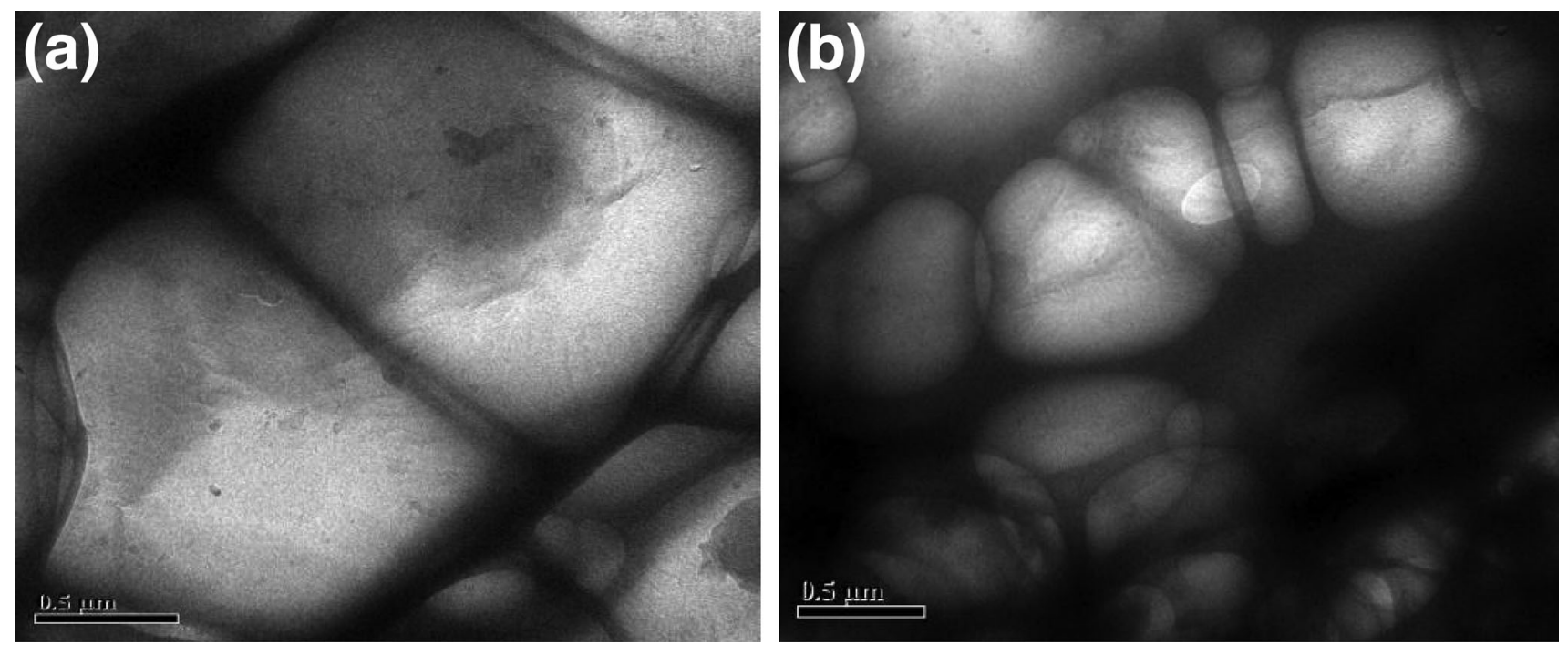

Fig. 5 TEM image of lipid globules accumulated inside the bacteria:

(a) control biomass and (b) heavy metal loaded biomass

literature reports that microbial biosorption significantly influences the biodegradation of recalcitrant compounds (Roy et al. 2015; Lu and Zhu 2012; Sokhn et al. 2001). Bueno et al. (2008) investigated the sorption capacity of non-viable $R$. opacus to bind with heavy metals $(\mathrm{Pb}, \mathrm{Cu}$, and $\mathrm{Cr}$ ) from aqueous environment and observed that the sorption phenomena followed the pseudo-second order kinetics. In the literature, Chen et al. (2013) also reported that $\mathrm{Cu}(\mathrm{II})$ inhibited benzo [a] pyrene biodegradation by Stenotrophomonas maltophilia owing to the bacterial cell wall damage.

\section{Characterization of the bacterial biomass}

\section{FESEM, EDX, and TEM analyses}

For understanding the changes in morphology and elemental composition of the $R$. opacus biomass grown in presence of the heavy metals, FESEM-EDX analysis of control biomass and the metal loaded biomass was performed. Figure $3 \mathrm{a}$, b clearly shows morphological difference in the bacterial cell due to the heavy metals. Figure 4a-f displays the EDX spectrum of the control and the heavy metal loaded biomass, which clearly reveals an extra peak due to the respective heavy metals on the biomass. These results confirmed that heavy metal uptake by the bacteria is due to biosorption. The inhibitory effect of the heavy metals on lipid accumulation by the bacterium is evident from the small-sized globules of the biomass observed under TEM (Fig. 5a, b). Whereas Fig. 5a shows TEM image of control biomass grown without any heavy metals, Fig. 5b shows TEM image of biomass grown in the presence of heavy metals.

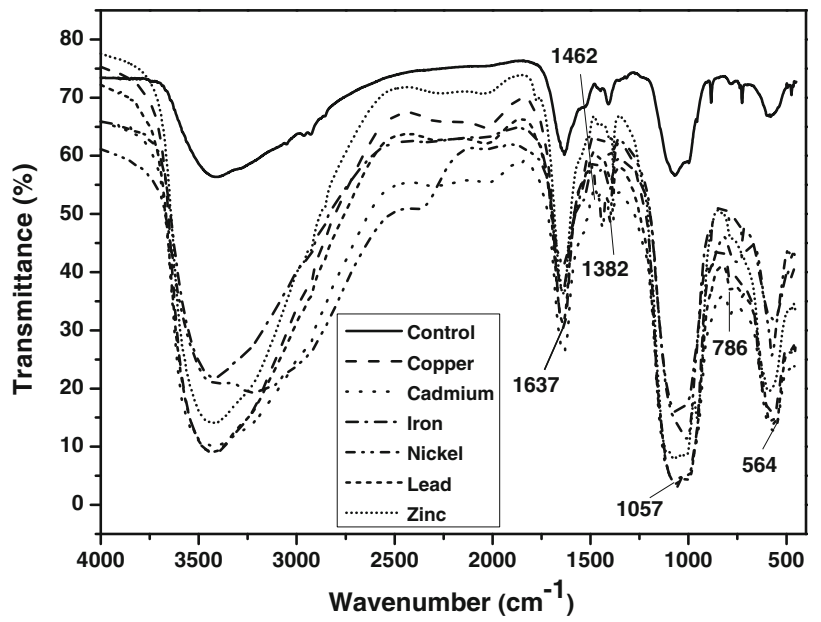

Fig. 6 FTIR spectra of control biomass and metal loaded biomass

\section{FTIR spectroscopy analysis}

The bacterial biomass obtained from the experiments was further characterized utilizing Fourier transform infrared (FTIR) spectrometer to identify the interaction between the heavy metal ions and the functional group involved on the bacterial surface (Fig. 6). The control biomass depicted strong peaks at 1637, 1462, 1382, 1057, 786, and $564 \mathrm{~cm}^{-1}$, which are attributed to primary amine of proteins (amide III, $-\mathrm{N}-\mathrm{H})$ stretch $\left(1650-1580 \mathrm{~cm}^{-1}\right), \mathrm{C}-\mathrm{H}$ alkane bend $\left(1470-1450 \mathrm{~cm}^{-1}\right),-\mathrm{CH}_{2}-(\mathrm{C}=\mathrm{O})$ stretch (1400-1370 $\left.\mathrm{cm}^{-1}\right)$, secondary amide $\gamma(\mathrm{N}-\mathrm{H})+\mathrm{v}(\mathrm{C}-\mathrm{N}),-$ $\mathrm{SO}_{3} \mathrm{H}$ stretch, pyridine (I) $\beta(\mathrm{C}-\mathrm{H})$ and pyridine (II) $\beta(\mathrm{C}-\mathrm{H})$ $\left(1300-850 \mathrm{~cm}^{-1}\right), \quad \mathrm{C}-\mathrm{H}$ and $\mathrm{O}-\mathrm{H}$ bending stretch $\left(750-700 \mathrm{~cm}^{-1}\right)$, and alkyl halide $(-\mathrm{C}-\mathrm{Cl})$ stretch $\left(850-550 \mathrm{~cm}^{-1}\right)$, respectively (Ye et al. 2013). Comparison of the spectra due to control biomass with that of the 
heavy metal loaded biomass reveals that $\mathrm{N}-\mathrm{H}, \mathrm{C}-\mathrm{H}$ bend, $-\mathrm{CH}_{2}-(\mathrm{C}=\mathrm{O}), \mathrm{C}-\mathrm{N}$ stretch, $\mathrm{C}-\mathrm{H}$ and $\mathrm{O}-\mathrm{H}$ bending, and $-\mathrm{C}-\mathrm{Cl}$ stretch participated in heavy metal binding by the bacterium. These FTIR results confirm the involvement of peptidoglycan present in the bacterial cell wall for heavy metal binding (Wei et al. 2011).

\section{Conclusions}

This study demonstrated simultaneous heavy metal removal and anthracene biodegradation by Rhodococcus opacus. However, heavy metal biosorption by the bacterium negatively influences its biomass growth, anthracene biodegradation, and total lipid accumulation. The heavy metal effect followed the order: $\mathrm{Cd}>\mathrm{Ni}>\mathrm{Pb}>\mathrm{Cu}>\mathrm{Zn}>\mathrm{Fe}$. The qualitative assessment of negative effect imposed by heavy metals on the biomass surface and lipid accumulation was successfully characterized using FESEM and TEM analyses. FESEM-EDX analysis of the bacteria biomass further confirmed that the metal precipitates formed were associated with the cell surface. FTIR characterization of the biomass grown in the absence and presence of the metals further confirmed the involvement of $\mathrm{N}-\mathrm{H}, \mathrm{C}-\mathrm{H}$ bend, $-\mathrm{CH}_{2}-$ $(\mathrm{C}=\mathrm{O}), \mathrm{C}-\mathrm{N}$ stretch, $\mathrm{C}-\mathrm{H}$ and $\mathrm{O}-\mathrm{H}$ bending, and $-\mathrm{C}-\mathrm{Cl}$ groups on the biomass for heavy metal binding by the bacteria. Overall, this study proved the potential of the strain to remove both organic and inorganic pollutants from mixture as well as accumulate lipid inside by utilizing such recalcitrant pollutants. The accumulated lipids can further be transesterified for its potential biodiesel application.

Acknowledgements The authors thank the Center for the Environment, Indian Institute of Technology Guwahati, for providing the necessary facilities to carry out this research work. The authors also acknowledge Central Instrument Facility (CIF), IIT Guwahati, for FESEM, EDX and TEM analyses. Authors greatfully acknowledge Mr. Rupak Kishor for his help in EDX analysis.

\section{Compliance with ethical standards}

Conflict of interest The authors of this work declare that they have no conflict of interest.

Open Access This article is distributed under the terms of the Creative Commons Attribution 4.0 International License (http:// creativecommons.org/licenses/by/4.0/), which permits unrestricted use, distribution, and reproduction in any medium, provided you give appropriate credit to the original author(s) and the source, provide a link to the Creative Commons license, and indicate if changes were made.

\section{References}

Alexander M (1999) Biodegradation and bioremediation. Gulf Professional Publishing, The University of Michigan
American Public Health Association (APHA) (2005) Standard methods for examination of water and wastewater. American Water Works Association, Water Environment Federation, Washington DC

Arul Manikandan N, Alemu AK, Goswami L, Pakshirajan K, Pugazhenthi G (2016) Waste litchi peels for $\operatorname{cr}(v i)$ removal from synthetic wastewater in batch and continuous systems: sorbent characterization, regeneration and reuse study. J Environ Eng 142(9):C4016001

Atagana HI (2006) Biodegradation of polyacyclic aromatic hydrocarbons in contaminated soil by biostimulation and bioaugmentation in the presence of copper (II) ions. World J Microbiol Biotechnol 22:1145-1153

Bååth E (1989) Effects of heavy metals in soil on microbial processes and populations (a review). Water Air Soil Pollut 47:335-379

Baldrian P, Gabriel J, Nerud F, Zadražil F (2000) Influence of cadmium and mercury on activities of ligninolytic enzymes and degradation of polycyclic aromatic hydrocarbons by Pleurotus ostreatus in soil. Appl Environ Microb 66:2471-2478

Bücker M, Glatt HR, Platt KL, Avnir D, Ittah Y, Blum J, Oesch F (1979) Mutagenicity of phenanthrene and phenanthrene K-region derivatives. Mutat Res- Genet Tox 66:337-348

Bueno BYM, Torem ML, Molina FALMS, De Mesquita LMS (2008) Biosorption of lead (II), chromium (III) and copper (II) by $R$. opacus: equilibrium and kinetic studies. Miner Eng 21:65-75

Cerniglia CE, Heitkamp MA (1989) Microbial degradation of polycyclic aromatic hydrocarbons (PAH) in the aquatic environment. Metabolism of polycyclic aromatic hydrocarbons in the aquatic environment. CRC Press, Inc., Boca Raton, Florida, pp 41-68

Chen S, Yin H, Ye J, Peng H, Zhang N, He B (2013) Effect of copper (II) on biodegradation of benzo [a] pyrene by Stenotrophomonas maltophilia. Chemosphere 90:1811-1820

Daane LL, Harjono I, Barns SM, Launen LA, Palleron NJ, Häggblom MM (2002) PAH-degradation by Paenibacillus spp. and description of Paenibacillus naphthalenovorans sp. nov., a naphthalene-degrading bacterium from the rhizosphere of salt marsh plants. Int J Syst Evol Micr 52:131-139

Das K, Mukherjee AK (2007) Differential utilization of pyrene as the sole source of carbon by Bacillus subtilis and Pseudomonas aeruginosa strains: role of biosurfactants in enhancing bioavailability. J Appl Microbiol 102:195-203

Folch J, Lees M, Sloane-Stanley GH (1957) A simple method for the isolation and purification of total lipids from animal tissues. $\mathbf{J}$ boil Chem 226:497-509

Gopi Kiran M, Pakshirajan K, Das G (2015) Heavy metal removal using sulfate-reducing biomass obtained from a lab-scale upflow anaerobic-packed bed reactor. J Environ Eng 142(9):C4015010

Hadibarata T, Kristanti RA (2012) Identification of metabolites from benzo [a] pyrene oxidation by ligninolytic enzymes of Polyporus sp. S133. J Environ Manage 111:115-119

Haritash AK, Kaushik CP (2009) Biodegradation aspects of polycyclic aromatic hydrocarbons (PAHs): a review. J Hazard Mater 169:1-15

Hiroki Y, Kadzunori T, Tosiharu U (1985) Fungal flora of soil polluted with copper. Soil Biol Biochem 17:785-790

Kiran MG, Pakshirajan K, Das G (2016) Heavy metal removal from multicomponent system by sulfate reducing bacteria: mechanism and cell surface characterization. J Hazard Mater 324:62-70

Kumar S, Gupta N, Pakshirajan K (2015) Simultaneous lipid production and dairy wastewater treatment using Rhodococcus opacus in a batch bioreactor for potential biodiesel application. J Environ Chem Eng 3:1630-1636

Kurosawa K, Boccazzi P, de Almeida NM, Sinskey AJ (2010) Highcell-density batch fermentation of Rhodococcus opacus PD630 
using a high glucose concentration for triacylglycerol production. J Biotechnol 147:212-218

Lee EH, Cho KS (2009) Effect of substrate interaction on the degradation of methyl tert-butyl ether, benzene, toluene, ethylbenzene, and xylene by Rhodococcus sp. J Hazard Mater 167:669-674

Lu L, Zhu L (2012) Effect of soil components on the surfactantenhanced soil sorption of PAHs. J Soils Sediments 12:161-168

Mahanty B, Pakshirajan K, Dasu VV (2008) Synchronous fluorescence as a selective method for monitoring pyrene in biodegradation studies. Polycycl Aromat Comp 28:213-227

Maria VL, Gomes T, Barreira L, Bebianno MJ (2013) Impact of benzo (a) pyrene, $\mathrm{Cu}$ and their mixture on the proteomic response of Mytilus galloprovincialis. Aquat Toxicol 144:284-295

Mehta V, Chavan A (2009) Physico-chemical treatment of tarcontaining wastewater generated from biomass gasification plants. World Acad Sci Eng Technol 57:161-168

Nam IH, Kim Y, Cho D, Kim JG, Song H, Chon CM (2015) Effects of Heavy Metals on biodegradation of fluorene by a Sphingobacterium sp. strain (KM-02) isolated from polycyclic aromatic hydrocarbon-contaminated mine soil. Environ Eng Sci 32:891-898

Pavasant P, Apiratikul R, Sungkhum V, Suthiparinyanont P, Wattanachira S, Marhaba TF (2006) Biosorption of $\mathrm{Cu}^{2+}, \mathrm{Cd}^{2+}$, $\mathrm{Pb}^{2+}$, and $\mathrm{Zn}^{2+}$ using dried marine green macroalga Caulerpa lentillifera. Bioresour Technol 97:2321-2329

Riis V, Babel W, Pucci OH (2002) Influence of heavy metals on the microbial degradation of diesel fuel. Chemosphere 49:559-568

Roy AS, Hazarika J, Manikandan NA, Pakshirajan K, Syiem MB (2015) Heavy metal removal from multicomponent system by the cyanobacterium Nostoc muscorum: kinetics and interaction study. Appl Biochem Biotechnol 175:3863-3874
Samanta SK, Singh OV, Jain RK (2002) Polycyclic aromatic hydrocarbons: environmental pollution and bioremediation. Trends Biotechnol 20:243-248

Sasek V, Glaser JA, Baveye P (2003) The utilization of bioremediation to reduce soil contamination: problems and solutions (proceedings NATO advanced research workshop on the utilization of bioremediation to reduce soil contamination: problems and solutions, Prague, Czech Republic, 14-19 June 2000) (Vol. 72). Springer Science and Business Media, Netherlands

Sokhn J, De Leij FAAM, Hart TD, Lynch JM (2001) Effect of copper on the degradation of phenanthrene by soil micro-organisms. Lett Appl Microbiol 33:164-168

Titaley IA, Chlebowski A, Truong L, Tanguay RL, Massey Simonich SL (2016) Identification and toxicological evaluation of unsubstituted PAHs and novel PAH derivatives in pavement sealcoat products. Environ Sci Technol Lett 3(6):234-242

Wei X, Fang L, Cai P, Huang Q, Chen H, Liang W, Rong X (2011) Influence of extracellular polymeric substances (EPS) on $\mathrm{Cd}$ adsorption by bacteria. Environ Pollut 159:1369-1374

Wieczorek J, Sienkiewicz S, Pietrzak M, Wieczorek Z (2015) Uptake and phytotoxicity of anthracene and benzo [k] fluoranthene applied to the leaves of celery plants (Apiumgraveolens var. secalinum L.). Ecotoxicol Environ Saf 115:19-25

Yap CL, Gan S, Ng HK (2011) Fenton based remediation of polycyclic aromatic hydrocarbons-contaminated soils. Chemosphere 83:1414-1430

Ye J, Yin H, Xie D, Peng H, Huang J, Liang W (2013) Copper biosorption and ions release by Stenotrophomonas maltophilia in the presence of benzo [a] pyrene. Chem Eng J 219:1-9 